\title{
Süt Sığırlarında Postpartum Anöstrüs
}

\author{
Uğur Şen, Ömer Gülboy \\ Ondokuz Mayıs Üniversitesi, Ziraat Fakültesi, Zootekni Bölümü, 55139, Atakum, Samsun \\ e-posta: ugur.sen@ omu.edu.tr; Tel: +90 (362) 312 1919; Faks: +90 (362) 4576034
}

\begin{abstract}
Özet
Postpartum anöstrüs süt sığırlarının doğum sonrasında kızgınlık döngüsünün görülmediği dönem olarak bilinir. Süt sığırlarında postpartum anöstürün uzaması üreme etkinliğini sınırlayan en temel etmenlerden biridir. Postpartum anöstrüs yetersiz beslenme, süt verimi ve çeşitli patolojik etmenler (kronik zayıf düşürücü hastalıklar veya uterus ve ovaryum hastalıkları) gibi pek çok faktörden kaynaklanmaktadır. Anöstrüsün engellenmesi uygun beslenme, tedavi yöntemleri (hormon muamelesi) ve yeterli sağlık tedbirlerinin alınmasıyla gerçekleştirilebilir. Anöstrüs’ün nedenini tam olarak anlayabilmek ve engelleyebilmek için, a) üremeyi etkileyen doğum öncesi hastalıkların b) ovulasyon ile ilgili genlerin c) metabolik sinyaller ile nöroendokrin döngü arasındaki önemli bağlantı fonksiyonu gören bazı proteinlerin (leptin), anöstrüs üzerine olan etkilerinin belirlenmesi gerekmektedir. Bu derlemede postpartum anöstrüs ile ilgili ovaryum aktiviteleri üzerinde durulmuştur.
\end{abstract}

Anahtar kelimeler: Anöstrüs, fertilite, postpartum, süt sığırı

\section{Postpartum Anestrus in Dairy Cattle}

\begin{abstract}
After giving birth, dairy cattle go through a period when they do not display estrous cycles are known as postpartum anestrus. Prolonged postpartum anestrus is one of the main factors limiting reproductive efficiency in dairy cattle. Postpartum anestrus is caused by several factors such as malnutrition, milk yield and pathologic conditions (chronic debilitating diseases or uterine and ovarian diseases). Prevention of anestrus is preferable to nutrition, treatment (hormone treatment) and can be achieved sufficient health measures. Its prevention it must be determined the effects of, a) peripartum disease conditions that influence reproduction b) genes involved in ovulation c) the influence of proteins (leptin) that appear to be important links between metabolic signals and the neuroendocrine axis. This review focuses on ovarian activity associated with postpartum anoestrous.
\end{abstract}

Key words: Anestrus, fertility, postpartum, dairy cattle

\section{Giriş}

Anöstrüs kızgınlık döngüsünün şekillenmemesi veya kızgınlık belirtilerinin görülmemesi şeklinde tanımlanmaktadır (Kamal ve ark., 2014). Anöstrüs doğum sonrası (postpartum) dönemde yaygın olarak görülmekte olup, doğum ile gebe kalma arasındaki süreyi (Servis periyodu) uzatmakta ve ekonomik kayıplara neden olmaktadır (Kamal ve ark., 2014). Düzenli buzağılama aralığı için postpartum ovaryum faaliyetlerinin sorunsuz bir şekilde sürdürülmesi gerekmektedir (Beam ve Butler, 2000). Bunun için yüksek verimli süt sığırlarında laktasyonun 50 ile 60 . günlerinde ortaya çıkan negatif enerji balansının ideal olan en kısa sürelere getirilmesi gerekmektedir (Harrison ve ark 1990). Çünkü laktasyonun bu dönemindeki süt verimi pik seviyelere ulaştığından dolayı vücuda alınana enerjinin tamamı süt üretimi için kullanılmakta ve bu durum folliküler faaliyetlerin yeniden başlamasını geciktirip postpartum anöstrüs sürenin uzamasına neden olmaktadır (Harrison ve ark
1990; Beam ve Butler, 2000). Ayrıca düşük vücut kondisyonu ve postpartum hastalıklar da folliküler faaliyetlerin başlamasını geciktirerek postpartum anöstrüsün süresini uzatmaktadır (McDougall ve ark., 1995; Mateus ve ark., 2002). Dahası kızıınlıklarının gözden kaçırılması ve sakin kızgınlıkların tespit edilememesi bu süreyi uzatmaktadır (Kamal ve ark., 2012).

Son zamanlarda postpartum anöstrüs, folliküler ve luteal gelişim üzerine temellendirilerek sınıflandırılmaktadır (Wiltbank ve ark., 2002). Postpartum anöstrüs, minimum folliküler gelişim, ovulasyonun gerçekleşmemesi ve corpus luteum (CL) oluşmaması, silik ovulasyon veya östrus davranışı olamadan ovulasyonun gerçekleşmesi, kaybolmayan dominant follikülden kaynaklı ovaryumun faaliyetlerinin azalmas1, kistik ovaryum veya ovule olamayan folliküllerin kistleşmesi ve kaybolmayan CL gibi çeşitli folliküler ve luteal olaylara göre sinıflandırılmaktadır. $\mathrm{Bu}$ derleme, postpartum anöstrüs süresi üzerine ekili olan negatif enerji balansıla birlikte ovaryum 
aktivitelerinin başlaması ve devam etmesi üzerine etkili olan faktörler üzerinde durulmaya çalışılmıştır.

\section{Doğum Sonrası Ovaryum Aktivitelerinin Yeniden Başlaması}

Doğum sonrasındaki 42 gün boyunca (puerperium dönem) uterus involüsyonu gerçekleşmekte, düzenli kızgınlık döngüsüne yol açan gonadotropik/gonadal hormonların döngüsel salınımı yeniden başlamakta ve ilk ovulasyon gerçekleşmektedir. Genel olarak sığırların $\%$ 90'inda ilk postpartum ovulasyon bu dönem içerisinde gerçekleşmesine rağmen, yüksek verimli süt sığırlarında bu süre yaklaşık 3 hafta daha uzun olabilmektedir (Sakaguchi, 2012).

Uterus hastalıkları ovaryum aktiviteleri üzerine etkili olabilmektedir. Uterus hastalıkları hipotalamustan salgilanan GnRH'yı (Gonadotropin Releasing Hormon) dolayısıyla hipofizden salgılanan Lüteinleştirici (LH) ve Follikül Stimüle Edici (FSH) hormonları baskılamakta ve ovaryum fonksiyonların geciktirmektedir (Mateus ve ark., 2002). Genel olarak uterus hastalıklarını üreme sistemi üzerine olan olumsuz etkisi iltihaplı enfeksiyonlardan kaynaklanmaktadır. Uterus hastalıklarının göstergelerinden birisi postpartum dönemin 3. haftasındaki yüksek $\mathrm{PGF}_{2 \alpha}$ konsantrasyonudur. Bu yüksek konsantrasyon erken ovaryum döngüsünün başlamasını puerperal enfeksiyon ortadan kalkıncaya kadar engellemektedir (Williams ve ark., 2007). Bu bağlamda fonksiyonel foliküllerin oluşması ve kızgınlık döngüsünün luteal aşamalarının gerçekleşmesi için uterusun enfeksiyonlardan korunmas1 gerekmektedir. Bütün bu durumlar metritisten dolayı $\mathrm{PGF}_{2 a}$ salınımının artmasının postpartum anöstrüsün uzamasına neden olabileceğini göstermektedir.

Buzağılamadan sonraki 85. gün içerisinde gebeliğin yeniden oluşması; uterus involüsyonuna, hipotalamus, hipofiz ve ovaryumlar arasındaki işbirliğine yüksek oranda bağlıdır (Bauman ve Currie, 1980). Süt sığırlarında postpartum dönemdeki yüksek süt üretimi için gerekli olan yüksek enerji ihtiyac1; üreme organlarının anatomik ve fizyolojik olarak bir sonraki gebeliğe hazır olmasını geciktirmekte (uterus involüsyonu) ve optimum fertilite için gerekli hipotalamus-hipofiz-gonadal aksin fonksiyonlarında gerilemeye neden olmaktadır (Bauman ve Currie, 1980).

Süt sığırlarında doğumdan sonraki FSH konsantrasyonundaki artış postpartum periyodun ilk haftasında başlamakta ve 10-14 gün içerisinde postpartum folliküler dalga (3-5 follikül, 4-6 mm çapında) görülmektedir. FSH konsantrasyonu azaldığında bir follikül büyümeye devam etmekte ve dominant follikülü oluşturmaktadır (Rajamahendran ve Taylor, 1990). Bu dominant follikülün FSH salınımını ve yeni bir folliküler dalganın ortaya çıkışını baskıladığına da inanılmaktadır. Çünkü dominant folikülün granuloza hücrelerinden salgılanan inhibin, östrojen ve follistatin hormonları FSH salgılanmasını baskılamaktadır (Rajamahendran ve Taylor, 1990).

\section{Negatif Enerji Balansı ve Postpartum Üreme}

Negatif enerji balansı vücuda alınan enerjinin yaşama ve verim için gerekli olan enerjiyi karşılayamadığ durumlarda ortaya çıkmaktadır. Doğum öncesi dönemde yüksek verimli süt sığırları nadiren negatif enerji balansı içerisine girerler. Doğumdan sonraki dönemde ise yükselen süt üretimi enerji ihtiyacını artırdığından dolayı çoğu süt sığırı negatif enerji balansı içersine girmektedir (Leroy ve ark., 2008). Negatif enerji balansına giren sığırlar vücutlarına aldıkları enerjinin çoğunu verim için kullandıklarından dolayı üreme faaliyetleri için gerekli olan enerjiyi verime veya yaşama payına yönlendirmektedir (Butler., 2000). Dolayısıyla negatif enerji balansına girmiş sığırın ovaryumundaki folliküllerin sayısı kısıtlanmakta, dominant follikülün büyümesi, gelişmesi ve maksimum büyüklüğe ulaşmasıyla birlikte ovulasyonu gecikmekte veya engellenmekte, östrus davranışları baskı altına alınmaktadır (Leroy ve ark., 2008). Dahası negatif enerji balansına girmiş sığırların kan glikoz, insülin ve IGF1 konsantrasyonlarının düşmesi LH salınımını azaltmakta ve ovulasyon gecikmesine neden olmaktadır (Butler, 2000).

Negatif enerji balansına giren yüksek verimli süt sığırları enerji açığını kapatmak için besin tüketimini artırma eğiliminde bulunmaktadırlar. Artan yem tüketimi karaciğerdeki kan akım hızını teşvik ederek kandaki androjenler, östrojenler, progestinler ve kortikosteroidler gibi steroid hormonların hızlı bir şekilde metabolize olmasına neden olur ve bu durum da ovulasyonu baskılayarak dominant folliküllerin ovulasyonunu ve luteal yıkımı geciktirir (Petersson ve ark., 2006).

\section{Anöstrüs Tipleri}

Genel olarak anöstrüs kızgınlılık ifadesinin eksikliği veya kızgınlık sinyallerinin yokluğu olarak tanımlanmaktadır (Lucy ve ark., 2007). Yüksek verimli süt sığırlarının doğası gereği özellikle erken postpartum dönem boyunca kızgınlık davranışları düşük oranda sergilenmektedir. $\mathrm{Bu}$ durum özellikle postpartum 
periyottaki ilk ovulasyon öncesi kızgınlık belirtilerinin açık bir şekilde gözlenememesine neden olmaktadır (Harrison ve ark., 1990). Dahas1 modern süt sığırcılı̆̆ında uygulanan yoğun kızgınlık takiplerinde bile bu dönemdeki kızgınlıkların belirlenme etkinliği düşük olabilmektedir. Bu sebeple sakin ovulasyon ve kızgınlığın saptanamaması anöstrüs oranını arttırmaktadır.

Anöstrüs folliküler ve luteal gelişime göre dört tip içerisinde sinıflandırılmaktadır. $\mathrm{Bu}$ sinıflandırma, folliküler büyüme esnasında ovaryumlardaki foliküllerin büyümesindeki 3 safhaya dayandırılmaktadır. Birinci safha $(4 \mathrm{~mm})$ folliküllerin ortaya çıkışı, safha $(9 \mathrm{~mm})$ sapma veya ayrılma, üçüncü safha $(10 \mathrm{~mm}$ 'den 20 mm'ye kadar) ise ovulasyondur (Wiltbank ve ark., 2002). Bu derlemede incelenen anöstrüsün dört tipi Şekil 1'de gösterilmiştir.

Anöstrüs Tip 1'de folliküler büyümeye başlar ve ortaya çıkmakta, fakat daha sonra sapma yada ayrılmayı gerçekleştiremeden durmaktadırlar. Bu durumun sebebi henüz tam olarak anlaşılamamasına rağmen yetersiz beslenmeden veya negatif enerji balansındaki yüksek enerji ihtiyacının karşılanamamasından kaynaklandığı düşünülmektedir. Çünkü yetersiz beslenme veya şiddetli enerji açığının, folliküllerin büyümesi ve dominant hale geçmesi için gerekli olan LH desteğini azalttığ belirtilmiştir (Jolly ve ark., 1995). Erken postpartum periyot esnasında negatif enerji balansının folliküler faaliyet üzerine olan etkileri Şekil 2'de gösterilmiştir.

Negatif enerji balansındaki bir süt sığıının LH salınımındaki azalma, östrojenin LH salınım sıklığı üzerine olan negatif feedback etkisinden kaynaklanmaktadır. Çünkü bu dönemdeki etki, hipotalamustaki mevcut östrojen reseptörlerindeki artıştan veya östrojenin hipotalamusa yaptığı negatif feedback etkinin diğer faktörlere göre daha baskın hale gelmesinden oluşmaktadır (Sheldon ve ark., 2002). Ek olarak cinsel olgunluğa ulaşmadan önceki anöstrüse benzer şekilde östrojen, hipotalamustan salgılanan GnRH sıkılığı üzerine bir baskı oluşturarak GnRH'nın nöral aktivitesini de azaltabilmektedir (Sheldon ve ark., 2002).

Anöstrüs Tip 2'de folliküler büyüme, sapma veya ayrılma gerçekleşmekte, daha sonrasında follikül gelişimi durmakta (atresia) ve gerilemektedir. Bazı durumlarda follikül dominant folliküle ulaştıktan sonra atresia olmaktadır (McDougall ve ark., 1995). Bu folliküler gerileme bir kaç gün sonra ortaya çıkacak yeni folliküler dalgaya neden olmakla birlikte, bu durum ilk ovulasyon öncesi geçmesi gereken aralığın süresini uzatan yaklaşık dokuz sıralı folliküler dalgaların oluşmasına da neden olmaktadır. Bazı folliküler ileri derecede dominant follikül halini alırlar, fakat ovulasyon öncesi gerilemeye başlarlar. Bu durumun görüldüğ̈̈ süt sığırlarında her 3-4 saatte 1 salımından az olmak üzere düşük LH salınım sıklığı tespit edilmiştir. $\mathrm{Bu}$ dominant folliküler çok düşük östrojenin üretimi gerçekleştirmekte, böylece dominant follikül tarafından üretilen östrojenin pozitif feedback etkisinde aksaklıklar meydana gelmektedir (McDougall ve ark., 1995).

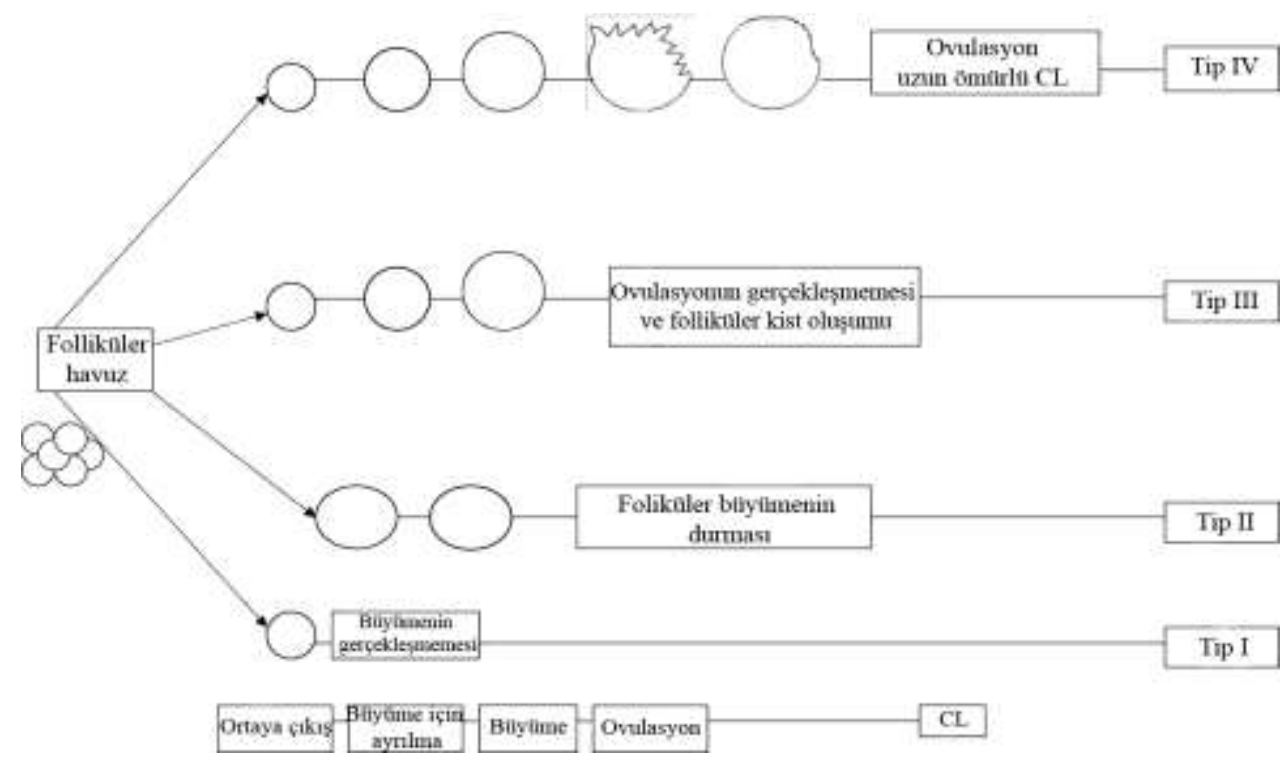

Şekil 1. Anöstrüs tiplerinin ovaryum folliküler ve luteal gelişime göre sınıflandırılması (Peter ve ark., 2009) 


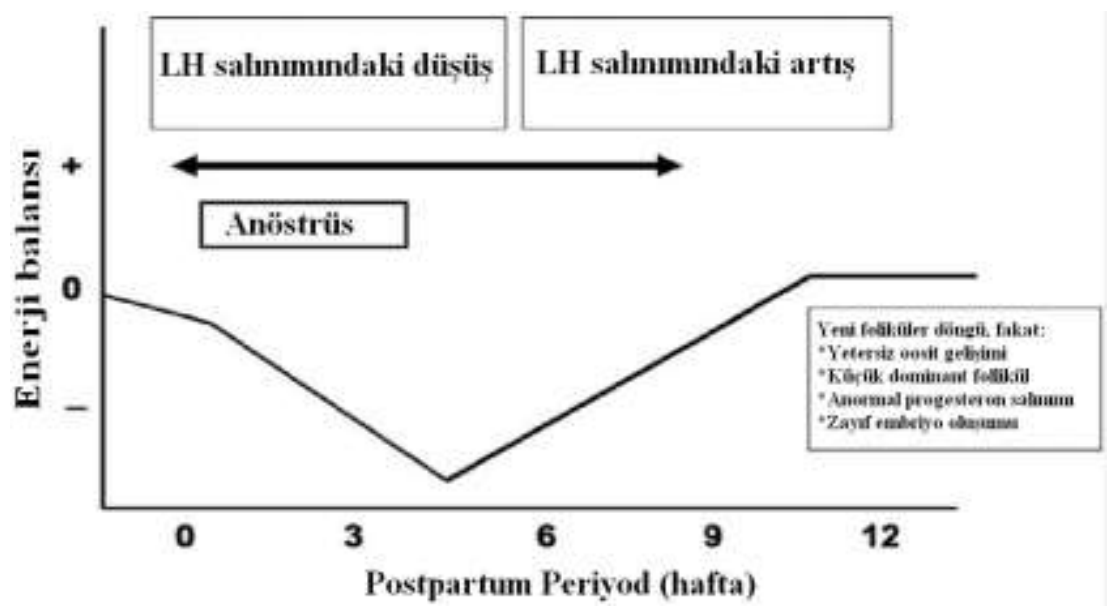

Şekil 2. Erken postpartum periyotta negatif enerji balansının üreme performansı üzerine etkisi (Peter ve ark., 2009)

Anöstrüs Tip 3'de folliküler büyüme, sapma veya ayrılma gerçekleşmekte ve dominant follikül oluşmaktadır. Fakat dominant follikül ovulasyonu gerçekleştiremez ve kalıcı bir folliküler yapı (kist) oluşturur. $\mathrm{Bu}$ durumun hipotalamusun östrojenin negatif feedback etkisine olan hassasiyetinin artmasindan ya da gonodotropik destek için metabolik hormonlar (IGF ve insülin) aracılığı ile olan folliküler yanıtın farklılaşmasından kaynaklanabileceği düşünülmektedir (Beam ve Butler, 1999). Kalıcı folliküler yapılar folliküler kistlere dönüşebilir ya da gerileyebilir. Kistlerin yapısal veya fonksiyonel durumu bir sonraki folliküler dalganın çeşitli aralıklar boyunca ortaya çıkışının baskılanıp baskılanmamasına bağlıdır (Sakaguchi ve ark., 2006).

Anöstrüs Tip 4 luteal fazın yani CL’a döngüye hakim olduğu dönemin uzamasından kaynaklanmaktadır. Bu durumdaki sığırlar luteal fonksiyonların uzamasının yanında normal bir kızgınlığa, ovulasyona ve CL'ye sahiptirler. $\mathrm{Bu}$ tip anöstrüs, luteal gerilemenin başlayacağı umulan zamanda gerekli olan östrojenik dominant follikülün oluşmasına engel olunmasından kaynaklanmaktadır (Wiltbank ve ark., 2002). Çünkü dominant follikülden gelen östrojen, uterus endometriumundaki oksitosin reseptörlerinin oluşmasını teşvik etmekte ve $\mathrm{PGF}_{2 \alpha}$ salınımının başlamasına ve salınım sıklı̆ğının artmasına yol açmaktadır. Böylece CL'nin yıkımı gerçekleşmekte ve yeni bir folliküler döngü başlayabilmektedir (Wiltbank ve ark., 2002). Luteal fazın uzamasını birçok faktör etkileyebilmektedir. Bunlardan en önemli olanları buzağılama sayısı, güç doğum, laktasyonun ilk aylarında gerçekleşen sağlık problemleri, sıcaklık stresi ve buzağılamadan çok kısa süre sonra gerçekleşen ovulasyondur (Opsomer ve ark., 2000). Ayrica uterus enfeksiyonları veya pyometra (uterusun progesterona aşırı şekilde duyarlı olma hastalığı) luteal fazın uzamasına neden olmaktadır (Sheldon ve ark., 2002).

\section{Anöstrüs Yönetimi}

Yüksek verimli süt sığırlarında ovulasyonun ve kistleşmenin olmadığı Tip 1 ve Tip 2 anöstrüslerin görülme oranı buzağılama sonrasındaki 50 ile 60 . günlerde $\% 11$ ile 38 arasında değişmektedir. Tip 1 ve Tip 2 anöstrüs'ün iyileştirilmesi, besleme rejimi ile düzeltilmesi çok zor olan negatif enerji balansının etkisinin hafifletilmesi ile gerçekleştirilebilir. Son zamanlarda kuruya alma döneminin kısaltılması veya tamamen ortadan kaldırılmasının da negatif enerji balansının üreme performansı üzerine olan etkilerini kısmen azatlığ saptanmıştır (Grummer, 2007). Dahası kuruda kalma süresinin kısaltılması postpartum metabolik problemlerin azalmasina ve erken laktasyondaki negatif enerji balansında düşmeye neden olmaktadır (Hossein-Zadeh ve Mohit, 2013). Ayrıca kuru dönemin uzunluğunu değiştirmeden bu dönemde rasyona katılan bazı yağ asitlerinin buzağılama sonrası ilk ovulasyonun gerçekleşme süresini kısalttığ saptanmıştır (Colazo ve ark.,. 2007). Kuru dönem hayvanın memelerini yeni laktasyon için hazırladığı ve kaybettiği vücut rezervlerini yerine koyduğu dönemdir. $\mathrm{Bu}$ dönem 40 günden daha az tutulursa hayvan memelerini gelecek laktasyon için yeterince yenileyip hazırlayamaz ve vücut rezervlerini tam olarak oluşturamadığ 1 için takip eden laktasyonda süt veriminde 100-600 kg civarında düşme gözlenebilir (Watters ve ark., 2013). Dolayisiyla postpartum anöstrüs'ün iyileştirilmesi için kuruya alma dönemini kısaltırken yukarıda belirtilen durumlarda göz ardı edilmemelidir. 
Yüksek verimli süt sığırlarında verim için gerekli olan enerji ihtiyacı tam olarak karşılanabiliyorsa durgun folliküllerin gelişimi için eksojen hormon uygulaması yapılabilir. Genel olarak anöstrüs postpartum dönemde olan veya kızgınlık döngüsünde olmayan sığırlar için kullanılan eksojen hormon progesterondur (Yaniz ve ark., 2004). Bununla birlikte progesteron uygulanmasından sonra gebe kısrak serumu, östrojen veya $\mathrm{PGF}_{2 \alpha}$ gibi hormonlar folliküler faaliyeti yeniden başlatmak ve maksimize etmek için kullanılmaktadır (Yaniz ve ark., 2004). Tip 1 ve Tip 2 anöstrüs durumuna sahip sığırlarda yapılan bir çalışmada östrojen ve GnRH muamelesinin ardından uygulanan 9. günlük vajina içi progesteron ve takibinde $\mathrm{PGF}_{2 \alpha}$ enjeksiyonunun kızgınlık oranında olumlu sonuçlar (889 sığırın 571'i kızgınlık göstermiştir; \%64 kızgınlık) verdiği saptanmıştır (Lopez-Gatius ve ark., 2008). Sürü içerisindeki her bir sığırın hormon muamelelerine olan cevapları farklı olabilir. Çünkü uygulanan muameleye verilen cevaplar anöstrüsün uzunluğunu belirleyen yaş, vücut kondisyonu, postpartum aralığı gibi faktörlere bağl1 olarak ortaya çıkarlar. Bu sebeple etkili bir hormon muamelesi için sürüdeki hayvanlar bireysel olarak değerlendirilmelidir.

Erken postpartum periyotta veya düşük vücut kondisyonuna sahip olan sığırlar hormon muamelelerine istenilen cevabı vermemektedir (Lopez-Gatius ve ark., 2008). Eksojen progesteron postpartum anöstrüs (Tip1 veya 2) veya kızgınlık döngüsünde olmayan sığırlar için en uygun tedavi yöntemi olsa da ovulasyonu teşvik edecek olan hormonal metotların iyi düzenlenmesi gerekmektedir (Lopez-Gatius ve ark., 2008). Bazı durumlarda anöstrüs sığırlar tek bir hormon tedavisine yanıt vermeyebilir ve ikinci bir tedaviye ihtiyaç duyulabilir. Yapılan bir çalışmada anöstrüs sığırlara 6 gün boyunca progesteron ve takibinde östrojen uygulanmıştır (McDougall ve Loeffler, 2004). Daha sonra tekrar 6 gün boyunca progesteron ve takibinde östrojen uygulanmıştır. $\mathrm{Bu}$ şekilde progesteron ve östrojenin birlikte kullanılması anöstrüs sığırların yeterli boyutta dominant folliküle sahip olmasına imkan sağlamaktadır. $\mathrm{Bu}$ durum aynı zamanda sığırların kızgınlık davranışlarını sergilemesine, LH dalgasına ve devamında sağlıklı bir oositin ovulasyonuna izin vermektedir (McDougall ve Loeffler, 2004).

Kistik folliküle sahip sığırlar progesteron, GnRH ve $\mathrm{PGF}_{2 \alpha}$ muameleleri ile başarılı bir şekilde tedavi edilebilir (Lopez-Gatius ve ark., 2001). Progesteron ile birlikte verilen östrojen hem kızgınlık döngüsündeki hem de anöstrüs sığırlardaki kalıcı dominant folliküllerin direncini kırmaktadır (Rhodes ve ark., 2002). Ancak bu muameleler bazı anöstrüs sığırlarda sonraki folliküler gelişmede gecikmeye de neden olabilmektedir (Rhodes ve ark., 2002). Kistik folliküllerin oluşmasını engellemek için ön hipofizden salgılanan LH'nın salınımını teşvik eden GnRH veya hCG de kullanılabilir. Kullanılan hormonların tipi ne olursa olsun eğer kistik follikül oluşmuşsa kistin yıkımını başlatmak için mutlaka $\mathrm{PGF}_{2 \alpha}$ kullanılmalıdır. $\mathrm{PGF}_{2 \alpha}$ ile muamele edilmiş sığırların \% 87 ile \% 96'sında 8 gün sonra kistlerin yıkımı gerçekleşmekte ve kızgınlığın görüntüsü ortaya çıkmaktadır (Crane ve ark., 2006). Ayrica GnRH ve $\mathrm{PGF}_{2 \alpha}$ kombinasyonu (0. gün $\mathrm{GnRH}$; 7. gün $\mathrm{PGF}_{2 \alpha}$; ve 9. gün $\mathrm{GnRH}$ ) ya da progesteron muamelesinin ardından $\mathrm{PGF}_{2 \alpha}$ ve eş zamanlı GnRH kullanılabilmektedir (Crane ve ark., 2006). Progesteron muamelesi kistik folliküle sahip sığırların hipotalamik fonksiyonlarını ve normal kızgınlık döngüsünü yeniden başlatabilmektedir. $\mathrm{Bu}$ durum muhtemelen progesteronun hipotalamustaki östrojen reseptörlerini teşvik ederek folliküler östrojene yanıt olarak bir GnRH/LH dalgası oluşturmasından kaynaklanmaktadır (Wiltbank ve Gumen, 2002). Anöstrüsün dördüncü türü için $\mathrm{PGF}_{2 \alpha}$ kalıcı CL'nin yıkımını gerçekleştirmek ve kızgınlık döngüsünü yeniden başlatmak için kullanılır (Farin ve Estill, 1993). Eğer CL'nin kalıcılığı uterustaki şiddetli iltihaplanmadan kaynaklanıyorsa, miktarına bağlı olarak sistematik antibiyotiklerle birlikte $\mathrm{PGF}_{2 \alpha}$ muamelesi daha faydalı olacaktır (Farin ve Estill, 1993).

Uygulanan bütün bu muameleler hayata geçirilmeden önce ekonomik analizlerinin yapılarak işletmeye getirisinin ne olacağı iyi belirlenmelidir. Bu belirlenme yapılırken sığırların gebe kalmadıkları sürenin azaltılmasının da dikkate alınması gerekmektedir. Dahası laktasyondaki süt sığırlarında bu hormon uygulamalarının yasal kullanım düzeyleri ve şartları da göz önünde bulundurulmalıdır. Anöstrüs'ün tedavisi için birçok hormonal muamele olmasıyla birlikte uygulamada çok dikkatli olunmalı ve kullanılacak yöntem tekrar tekrar gözden geçirilmelidir. İşletme şartlarından kaynaklanan anöstrüslerin tedavisi hiçbir zaman hormon muamelesi ile yapılmamalıdır. Dahası bu şekilde kullanılan hormon muameleleri yada yanlış kullanılan hormonlar sığırın başka bir formdaki anöstrüse maruz kalmasına neden olabilmektedir.

\section{Anöstrüsün Engellenmesi}

Süt sığırı yetiştiriciliğinde yüksek süt verimi ve optimum üreme performansı karlılığa önemli katkı sağlamaktadır. Yüksek süt verimine sahip sığırların 
üreme performansında sürekli sorunlar olmasına rağmen, yüksek süt veriminin üreme performans1 üzerine mutlak bir etkisi olmadığını gösteren deliller de mevcuttur (Windig ve ark., 2005). Doğum öncesi dönemde yüksek verimli süt sığırlarının ihtiyaç duydukları çevre şartları ve sağlık korumanın sağlanması yüksek süt veriminin üreme performansı üzerindeki etkilerini azaltabilmektedir (Windig ve ark., 2005). Yüksek verimli süt sığırlarında kızgınlığın etkili bir şekilde tespit edilmesi, doğum esnasında yeterli vücut kondisyonuna sahip olunması ve buzağılama sonrası en az canlı ağırlık kaybedecek şekilde beslenmenin gerçekleştirilmesi üreme performansını kabul edilebilir seviyeye çekilebilmektedir (Windig ve ark., 2005).

Postpartum dönemde optimum üreme performansı için; doğum öncesi dönemdeki metabolik rahatsılıklar tamamen ortadan kaldırılması ve buzağılama sonrası süt üretimi için gerekli olan kuru madde ihtiyacının hızlı bir şekilde vücuda alınması gerekmektedir. Yüksek verimli süt sığırlarında postpartum dönemdeki üreme performansının iyileştirilmesi, karaciğer yağlanması ve uzun süreli negatif enerji balansının önüne geçilmesiyle mümkün olmaktadır (Van den Top ve ark., 1995). Süt sığırlarında kuru dönemi kısaltmak veya tamamen ortadan kaldırmak enerji durumunu iyileştirebilir ve üreme performansını artırabilir (Grummer, 2007). Buzağılama dönemindeki aşırı yağlanma iştahı düşürerek erken postpartum periyottaki enerji alımının düşmesine neden olmaktadır. Karaciğer yağlanması sonucunda kan plazmasındaki esterleşmemiş yağ asitlerinin (NEFA) konsantrasyonu artmaktadır (Wentink ve ark., 1997). Hepatik NEFA okside edilerek veya esterleştirilerek trigliseride dönüştürülür ve çok düşük yoğunluktaki lipoproteinin bir parçası olarak kullanıldıktan sonra uzaklaştırılır veya depolanır (Wentink ve ark., 1997). Ruminantlarda trigliseridlerin uzaklaştırılması diğer birçok türe göre çok daha yavaş gerçekleşmektedir. Bu nedenle hepatik NEFA alımının yükseldiği koşullarda trigliserid birikimi artmaktadır. Böylece ruminantların yetersiz lipoprotein sentezinden dolayı karaciğerde yüksek oranda trigliserid birikimi gerçekleşmektedir (Wentink ve ark., 1997). Karaciğer yağlanması hipotalamus-uterus-gonadal aks üzerine doğrudan bir etkiye sahip olmamasına rağmen, bağışıklık sistemini zayıflattığı için dolaylı bir etkiye sahiptir (Van den Top ve ark 1995). Ayrıca bu durum enfeksiyonel ve metabolik hastalıkların oranının artış göstermesine neden olur (Mateus ve ark., 2002). Örneğin bu durumdaki süt sığırlarında yağ yıkımının başlamasıyla metritisin görülme oranı arasında pozitif bir ilişki vardır (Mateus ve ark., 2002).

Sonuç olarak süt verimi ve üreme performansı arasındaki ilişkide; karaciğerdeki trigliserid miktarı sabit kaldığı müddetçe süt verimindeki artışın üreme performans1 üzerine herhangi bir etkiye sahip olmayacağı söylenebilir. NEFA'nın yüksek seviyelerdeki alımının yaptığı zararlar tam olarak bilinmemesine rağmen son zamanlarda yapılan bazı çalışmalarda postpartum dönemde ovule olabilme potansiyelinde dominant folliküle sahip sığırların, sahip olmayanlara göre kan plazmalarında daha düşük oranda NEFA bulunduğu tespit edilmiştir (Butler, 2000). Bu durum NEFA ve trigliseridin hipotalamus-uterusgonadal aks üzerine olan kesin rolünün belirlenmesi için daha çok araştırmaya ihtiyaç duyulduğunu göstermektedir. Özet olarak NEFA ve trigliseridin üreme performansı üzerine olan etkileri sıcaklık stresi, yönetim faktörleri, yüksek üretim, metabolik hastalıklar, kaba yem tüketimi, sınırlı yemleme ve son olarak uterus durumuna (endometritis) gösterilen ilgi kadar önemli olabilir.

\section{Sonuç}

Son yıllarda yüksek verimli süt sığırlarının üreme performansları üzerine yapılan uygulamalarda önemli gelişmeler olmasına rağmen, fertilitede hala istenilen seviyeye ulaşılamamıştır. Ovaryum aktivitesinin başlaması ve normal kızgınlığın görülmesi üzerine etkili olan postpartum enerji dengesini iyileştirmelerin, anöstrüs süresinin kısaltılması için yapılan tedavilerinden daha etkili olduğu görülmektedir. Ayrıca postpartum anöstrüs süresinin kısaltılması için uygulanan hormon muamelelerinin hayvan refahı ve insan sağlığı açısından olumsuz bir etkiye sahip olmamasına rağmen, tüketicilerin bu muameleler ile ilgili olan endişelerinin de dikkate alınması gerekmektedir. $\mathrm{Bu}$ sebeple anöstrüs dönemdeki fertiliteyi iyileştirmek için yaygın bir şekilde kullanılan eksojen hormonlardan ziyade sürü yönetimi ile ilgili enerji ihtiyacı gibi faktörlerin üzerine odaklanılması ve bu faktörlerin iyileştirilmesi gerekmektedir.

\section{Kaynaklar}

Bauman, D.E., Currie, W.B. 1980. Partitioning of nutrients during pregnancy and lactation: a review of mechanisms involving homeostasis and homeorhesis. J. Dairy. Sci. 63: 1514-1529.

Beam, S.W., Butler, W.R. 2000. Effects of energy balance on follicular development and first ovulation in postpartum dairy cows. J. Reprod. Fertil. 54: 41124. 
Butler, W.R. 2000. Nutritional interactions with reproductive performance in dairy cattle. Anim. Reprod. Sci. 61: 449-457.

Colazo, M.G., Ambrose, D.J., Hayirli, A., Doepel, L. 2007. Prepartum feed restriction and fatty acid supplementation influence reproductive performance of dairy cows. J. Dairy. Sci. 90: 328.

Crane, M.B., Melendez, P., Bartolome, J., de Vries, A., Risco, C., Archbald, L.F. 2006. Association between milk production and treatment response of ovarian cysts in lactating dairy cows using the Ovsynch protocol. Theriogenology 66: 1243-1248.

Farin, P.W., Estill, C.T. 1993. Infertility due to abnormities of the ovaries in cattle. Vet. Clin. North. Am. Food. Anim. Pract. 9: 291-308.

Grummer, R.R. 2007. Strategies to improve fertility of high yielding dairy farms: management of the dry period. Theriogenology 68: 5281-5288.

Harrison, R.O., Ford, S.P., Young, J.W., Conley, A.J., Freeman, A.E. 1990. Increased milk production versus reproductive and energy status of high producing dairy cows. J. Dairy. Sci. 73: 2749-2758.

Hossein-Zadeh, N.G., Mohit A. 2013. Effect of dry period length on the subsequent production and reproduction in Holstein cows. Span. J. Agric. Res. 11(1): 100-108.

Jolly, P.D., McDougall, S., Fitzpatrick, L.A., Macmillan, K.L., Entwistle, K.W. 1995. Physiological effects of undernutriotn on postpartum anoestrous cows. J. Reprod. Fertil. 49: 477-492.

Kamal, M.M, Bhuiyan, M.M.U., Parveen, N., Momont, H.W., Shamsuddın, M. 2014. Risk factors for postpartum anestrus in crossbred cows in Bangladesh. Turk. J. Vet. Anim. Sci. 38(2): 151156.

Kamal, M.M., Rahman, M.M., Momont, H.W., Shamsuddin, M. 2012. Underlying disorders of postpartum anoestrus and effectiveness of their treatments in crossbred dairy cows. Asian J. Anim. Sci. 6: 132-139.

Leroy, J.L., Vanholder, T., Van Knegsel, A.T., GarciaIspierto, I., Bols, P.E. 2008. Nutrient prioritization in dairy cows early postpartum: mismatch between metabolism and fertility? Reprod. Domest. Anim. 43: 96-103.

Lopez-Gatius, F., Mirzaei, A., Santolaria, P., BechSa`bat, G., Nogareda, C., Garcia-lspierto, I. 2008. Factors affecting the response to the specific treatment of several forms of clinical anestrus in high producing dairy cows. Theriogenology 69: 1095-1103.

Lucy, M.C. 2007. Fertility in high-producing dairy cows: reasons for decline and corrective strategies for sustainable improvement. Soc. Reprod. Fertil.
Suppl. 64: 237-254.

Mateus, L., da Costa, L.L., Bernardo, F., Silva, J.R. 2002. Influence of puerperal uterine infection on uterine involution and postpartum ovarian activity in dairy cows. Reprod. Domest. Anim. 37: 31-35.

Mateus, L., da Costa, L.L., Bernardo, F., Silva, J.R. 2002. Influence of puerperal uterine infection on uterine involution and postpartum ovarian activity in dairy cows. Reprod. Domest. Anim. 37: 31-35.

McDougall, S., Burke, C.R., MacMillan, K.L., Williamson, N.B. 1995. Patterns of follicular development during periods of anovulation in pasture-fed dairy cows after calving. Res. Vet. Sci. 58: 212-216.

McDougall, S., Loeffler, S.H. 2004. Resynchrony of postpartum dairy cows previously treated for anestrus. Theriogenology 61: 239-53.

Opsomer, G., Grohn, Y.T., Hertl, J., Coryn, M., Deluyker, H., de Kruif, A. 2000. Risk factors for post partum ovarian dysfunction in high producing dairy cows in Belgium: a field study. Theriogenology 53: 841-857.

Peter, A.T., Vos, P.L., Ambrose, D.J. 2009. Postpartum anestrus in dairy cattle. Theriogenology 71(9): 1333-1342.

Petersson, K. J., Gustafsson, H., Strandberg, E., Berglund, B. 2006. Atypical progesterone profiles and fertility in Swedish dairy cows. J. Dairy. Sci. 89: 2529-2538.

Rajamahendran, R., Taylor, C. 1990 Characterization of ovarian activity in postpartum dairy cows using ultrasound imaging and progesterone profiles. Anim. Reprod. Sci. 22: 171-180.

Rhodes, F.M., Burke, C.R., Clark, B.A., Day, M.L., Macmillan, K.L. 2002. Effect of treatment with progesterone and oestradiol benzoate on ovarian follicular turnover in postpartum anoestrous cows and cows which have resumed oestrous cycles. Anim. Reprod. Sci. 69: 139-150.

Sakaguchi, M. 2012. Reproductive Potential of Japanese High-producing Dairy Cattle. Japan Agri. Res. Quart. 46(4): 311-319.

Sakaguchi, M., Sasamoto, Y., Suzuki, T., Takahashi, Y., Yamada, Y. 2006. Fate of cystic ovarian follicles and the subsequent fertility of early postpartum dairy cows. Vet. Rec. 159: 197-201.

Sheldon, I.M., Noakes, D.E., Rycroft, A.N., Pfeiffer, D.U., Dobson, H. 2002. Influence of uterine bacterial contamination after parturition on ovarian dominant follicle selection and follicle growth and function in cattle. Reproduction 123: 837-845.

Van den Top, A.M., Wensing, T., Gelen, M.J., Wentink, G.H., van’t Klooster, A.T., Beynen, A.C. 1995. 
Time trends of plasma lipids and enzymes synthesizing hepatic triacylglycerol during postpartum development of fatty liver in dairy cows. J. Dairy. Sci. 78: 2208-2220.

Watters, R., Fricke, P., Wiltbank, M., Clark, P., Grummer, R. 2013. Effect of dry period length on reproductive measures, health, and production of Holstein cows during the subsequent lactation. http://www.uwex.edu/ces/dairyrepro/documents/Con fDryPeriodManagement.pdf (Erişim: 02 Ekim 2014).

Wentink, G.H., Rutten, V.P.M.G., van den Ingh, T.S.G.A.M., Muller, K.E., Wensing, T. 1997. Impaired specific immunoreactivity in cows with hepatic lipidosis. Vet. Immunol. Immunopathol. 56: 77-83.
Williams, E.J., Fischer, D.P., Noakes, D.E., England, G.C., Rycroft, A., Dobson, H., Sheldon, I.M. 2007. The relationship between uterine pathogen growth density and ovarian function in the postpartum dairy cow. Theriogenology 68: 549-559.

Wiltbank, M.C., Gumen, A., Sartori, R. 2002. Physiological classification of anovulatory conditions in cattle. Theriogenology 57: 21-52.

Windig, J.J., Calus, M.P., Veerkamp, R.F. 2005. Influence of herd environment on health and fertility and their relationship with milk production. J. Dairy. Sci. 88: 335-47.

Yaniz, J.L., Murugavel, K., Lo'pez-Gatius, F. 2004. Recent developments in oestrous synchronization of postpartum dairy cows with and without ovarian disorders. Reprod. Domest. Anim. 39: 86-93 